\title{
Bibliometric Analysis of International Collaboration in Wind and Solar Energy
}

\author{
Ichiro Sakata ${ }^{1,2}$, Hajime Sasaki ${ }^{2}$ \\ ${ }^{1}$ Faculty of Engineering \\ The University of Tokyo, Tokyo, Japan \\ e-mail: isakata@ipr-ctr.t.u-tokyo.ac.jp \\ ${ }^{2}$ Policy Alternatives Research Institute \\ The University of Tokyo, Tokyo, Japan
}

Cite as: Sakata, I., Sasaki, I., Bibliometric Analysis of International Collaboration in Wind and Solar Energy, J. sustain. dev. energy water environ. syst., 1(3), pp 187-198, 2013, DOI:

http://dx.doi.org/10.13044/j.sdewes.2013.01.0014

\begin{abstract}
Modern technology is increasingly complex and demands an ever-widening range of knowledge and skills. No single country will possess all the knowledge and skills required for addressing global issues such as climate change. Technology collaboration between leading countries is important to promptly and efficiently address the problem. Previous studies have shown that a high level of collaboration is correlated with high paper productivity. This paper first aims to use objective data and create maps that enable us to see both the distribution of worldwide research competency and the relationship of international collaboration in clean energy research. In the international research network of wind power and solar cell, 4,189 institutions located in 121 countries and 6,600 institutions located in 125 countries are included respectively. This paper discusses various factors that would have an impact on research capability and support strong international relationships. With respect to research capability, governmental policies, stability of governmental commitment, natural conditions and historical and institutional differences have a significant impact on it. For research collaborations, factors such as geographical proximity, international science and technology policy, and developmental stage of technology have been brought to attention. This study demonstrates that bibliometrics is a methodology that is capable of providing a knowledge base that is useful in the development of the international science and technology policy and technological management strategy.
\end{abstract}

\section{KEYWORDS}

Wind Power, Solar Cell, Research Network, Bibliometrics, Science and Technology Policy

\section{INTRODUCTION}

Climate change is a common global issue. The development and extensive use of efficient and inexpensive renewable energy is the key to solve the issue. Advanced technology and the market for the products of current technologies to tackle the problem are spread throughout the world. Modern technology is increasingly complex and demands an ever-widening range of knowledge and skills. Often, no single country will possess all the knowledge and skills required. In addition to each country's commitment, technology collaboration between leading countries with a high level of science and industrial technology in the field is important to promptly and efficiently address the problem. Previous studies have shown that a high level of collaboration is correlated with high paper productivity [1-3]. In fact, momentum toward international collaboration is growing among international organizations including OECD and APEC. 
In recent years, there has been a significant improvement in knowledge and skills of non-hydro renewable energy research in Asian countries, as well as the US, the EU, and Japan [4]. This may have resulted from policies wherein these Asian countries have been investing in the development of world-class universities and encouraging doctoral degree holders, who studied overseas at leading universities, to return to their countries as key researchers [5]. Therefore, comprehensive understanding on this rapidly changing structure of global academic research and collaboration is essential for governments to design effective science policy in clean technologies. Awareness of this issue, Science of Science and Innovation Policy program (SciSIP) of US National Science Foundation and Japan's Science for RE-designing Science, Technology and Innovation Policy Program (SciREX) has been introduced. However, not many previous studies have been conducted on changes in geopolitical structure of clean energy research by using objective data. In particular, there are few empirical studies that focus on dynamic changes in Asia and describe the structure of international collaboration.

This paper will first aim to use objective data and create global maps that enable us to see both the distribution of worldwide research competency and the relationship of international collaboration. The maps will be a knowledge base to help design a policy for international research collaboration. This analysis focuses on two academic research fields: wind power and solar cell. In recent years, both have been the latest growing technologies, and both are expected to become promising solutions for environmental pollution and climate change in many countries. Second, we attempt to compare the structure of wind power and solar cell research networks. Then this paper discusses various factors that would have an impact on research capability and support strong international relationships. A bibliometric approach is used in this paper. This method is often used for the analysis of rapidly changing energy technologies [e.g., 6-8]. The number of papers in a country or organization is used as an indicator for the research competency of the country or organization. The number of internationally co-authored papers-papers authored by scientists affiliated with organizations in more than two countries - is used as an indicator for international collaboration. Even though human exchange and agreement of research cooperation between organizations are also indicators of collaboration, there are many studies that use co-authorship as a quantitative indicator [9,10 as pioneering studies]. Co-authorship is used as an indicator of international collaboration [3, 11-14]. Several studies using co-authorship have been conducted in the EU. Katz and Martin [15] point out four key advantages of using co-authorship as an indicator of collaboration including its verifiability, statistical significance, data availability, and ease of measurement. On the other hand, bibliometric analysis of multiple-author papers is not accurate as it can only be used to measure collaborative activities where the collaborating participants have entered their names on joint papers. We are aware of a bias where each research paper published separately despite the collaboration cannot be correctly identified. Nevertheless, this unique analytical method and data provides useful and clear empirical evidence, and when used with appropriate caution reveals new insights for international science policy. Due to the lack of empirical evidence, geopolitical factors have an excessive impact on the past decision of international science policy. In this paper, a country or an organization is the unit of measurement. The factors creating collaborations, such as language, culture, distance, history, political and economic factors, are discussed based on previous bibliometric studies $[3,11,12,14,16]$. This paper tries to identify factors contributing to international collaborations, according to bibliographic information of papers. 


\section{METHODOLOGY}

First, papers with the terms "wind power*" or "wind energy*" or "wind turbine*" or "windmill*" or "wind mill*" or "wind farm*" or "wind park*" or "wind flow*" or "wind industry*" or "wind resource*" or "wind technolog*" or "offshore wind*" or "onshore wind*" and "photovoltaic cell*" or "solar cell*" in their bibliographic information are selected from all the papers published in English between 1945 and 2010 using "Science Citation Index (SCI)" and "Social Science Citation Index (SSCI)", database by Thomson Reuters. The asterisk (*) in each search queries represents any group of characters, including no character.

The selected papers are defined as either papers on wind power or papers on solar cell. The papers with author information are then selected and grouped into two data sets: 7,299 papers on wind power, and 35,322 papers on solar cell. With respect to the bibliometric analysis of renewable energy technologies, the study by Sakata et al [4] exists as previous studies. The data on solar cell is the same with this study. Information such as the publishing year, author's organization, and country of the organization is extracted from the data sets. The numbers of organizations extracted are 4,189 for wind power and 6,660 for solar cell. The information of continent (Europe, Asia, North America, South America or Oceania) of the country extracted from is also annotated to the country information. In this paper, analysis is conducted within the scope of all the above-mentioned data. Even though major international journals tend to include authors from wider countries, we are aware of bias where we might underestimate the impact of the paper written in non-English.

Second, two types of data structure are developed: the data of research competency and of co-authorship. The data of research competency is obtained from the number of papers in each country or organization. It also provides time-series data. The data of co-authorship is led by calculating all combinations of co-authors based on information about the author's organization. For example, if four different authors write one paper, and each author belongs to a different organization, the paper is considered to include six co-authorship relations. In addition, a co-authorship is defined as an international co-authorship if the authors belong to organizations in different countries. The ratios of international co-authorship in wind and solar power are $19.3 \%$ and $14.2 \%$, respectively. Authors in co-authored papers are not weighted by the order listed.

Third, the data is visualized as a "research network map" with the author's organization as a node and co-authorship relation as a link between the nodes. In the maps, organizations are grouped into the country to which they belong. The combinations of organizations that have more co-authorship relations are also identified. Finally, we attempt to compare two maps and discuss factors underlying research collaboration.

\section{RESULT}

Although both energy sources are recognized as promising technologies, the number of papers on wind power is significantly lower than that on solar cell. Changes in the number of papers published in the top five countries and in the co-authorship rate in the top five countries are shown in Figure 1(a) (wind power) and Figure 1(b) (solar cell). Significant increases in the number of papers and the rate of international co-authorship have been identified from the results of the analysis. Although the order is different between the two figures, three countries simultaneously appear in both: US, Japan, and Germany. China ranks sixth and India ranks fourteenth in the number of papers on wind power. The number of papers in Asia is increasing rapidly. Most recently, China ranks second for both technologies on an annual basis. 
According to the figures, international co-authorship rate is significantly higher on wind power than on solar cell. Except for Japan, more than 50\% of the papers are co-authored internationally on wind power.
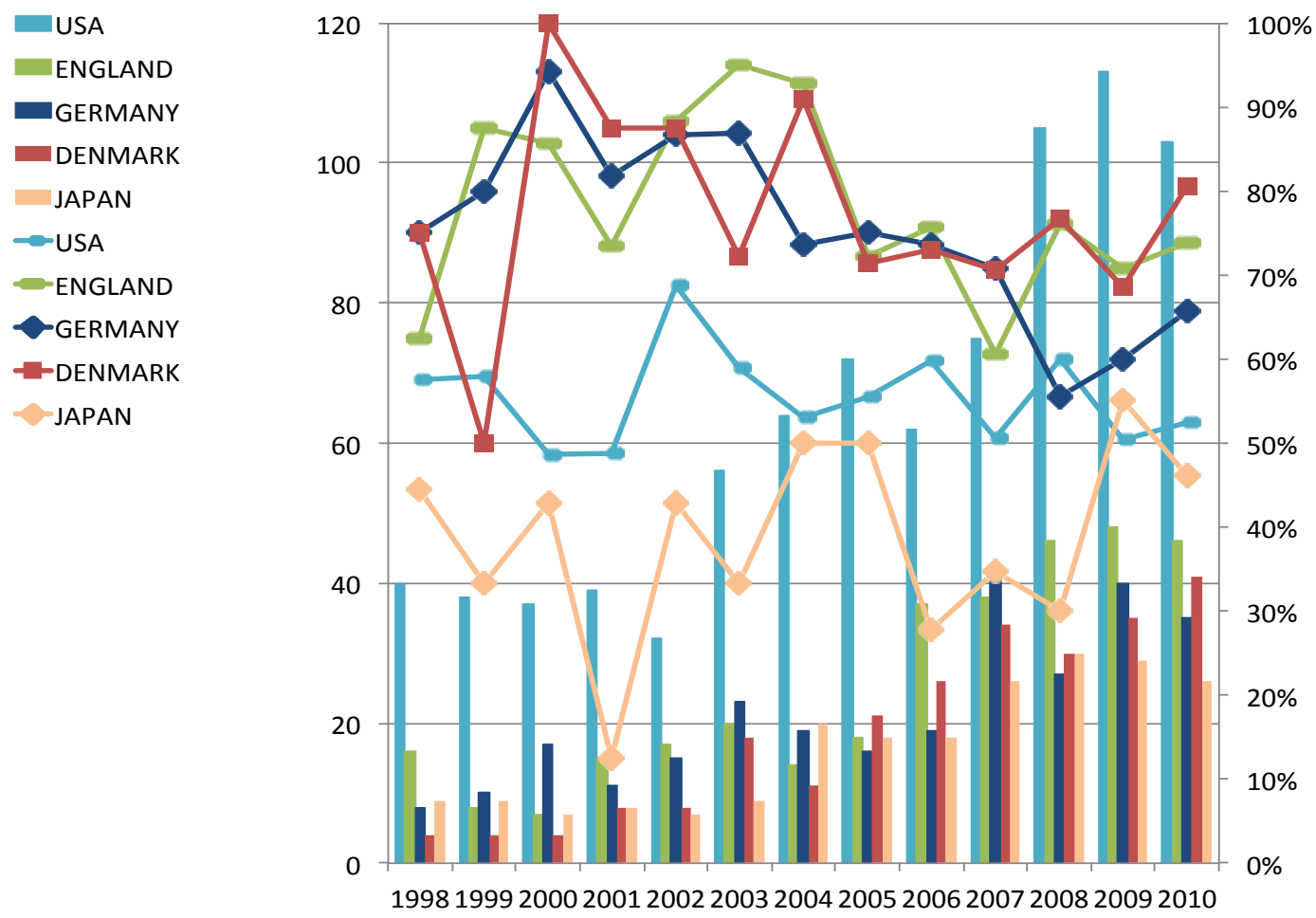

Figure 1(a). The Number of Papers and Share of International Co-authorship (Wind Power)

The bar plot shows the number of papers and the line plot shows the share of international co-authorship.
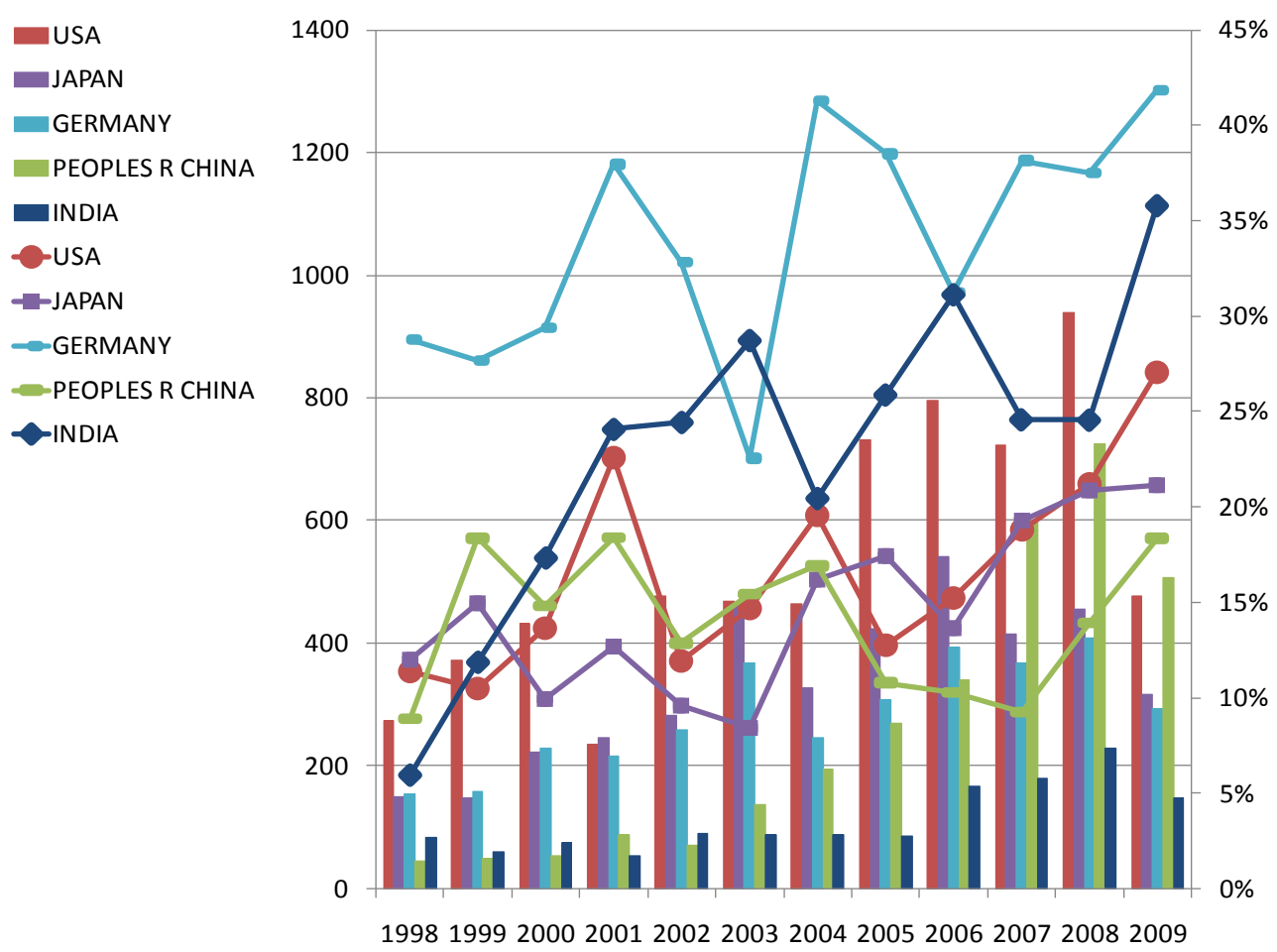

Figure 1(b). The Number of Papers and Share of International Co-authorship (Solar Cell) 
The bar plot shows the number of papers and the line plot shows the share of international co-authorship.

International research collaboration network obtained according to the information about research competency and co-authorship relations are shown in Figures 2(a) (wind power) and 2(b) (solar cell). Research organizations in the same country are placed together and shown as a node. The size of each node shows the number of papers written by authors from the country. Each link between two nodes of different countries indicates that there is a co-authorship between the organizations in those countries. The breadth of each link indicates the number of co-authorships between countries. Although both figures look similar, showing a well-balanced structure between North America, Asia, and Europe, there are three major differences between the two maps. First, the countries that play a major role as technology hubs for different technologies vary within Europe. For example, Germany is known for the study of solar cells, and England and the Scandinavian countries are known for their contribution to wind power. Second, the co-authorship relations between Asia and Europe/North America are more significant in the field of solar energy, even if the difference in the total number of citations is considered. On the other hand, co-authorship relations within Asia are closer in the field of wind power, even if the total number of citations is considered. Third, more African nations are participating in the research activities related to solar energy.

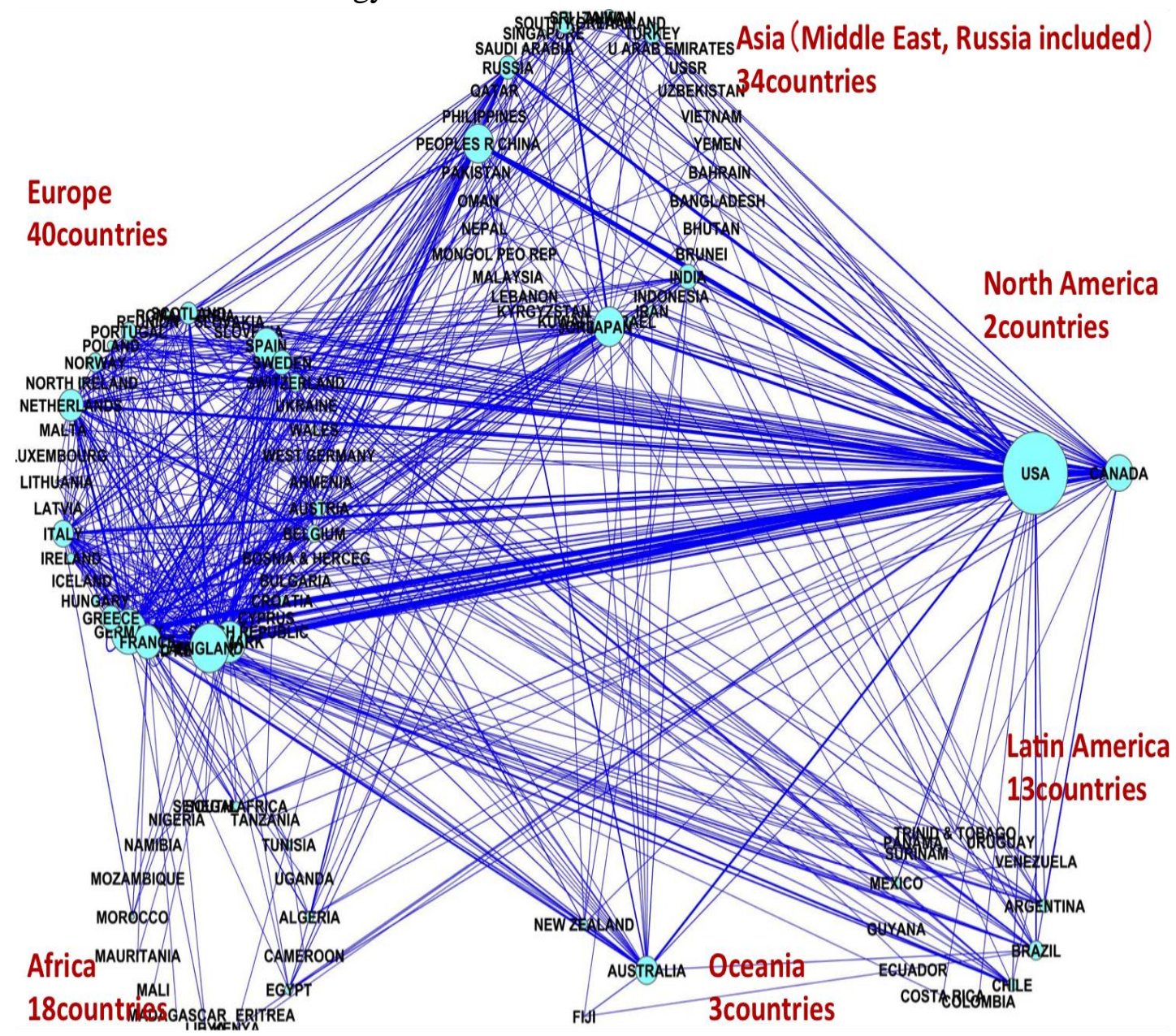

Figure 2(a). Research Network Diagram of Wind Power 


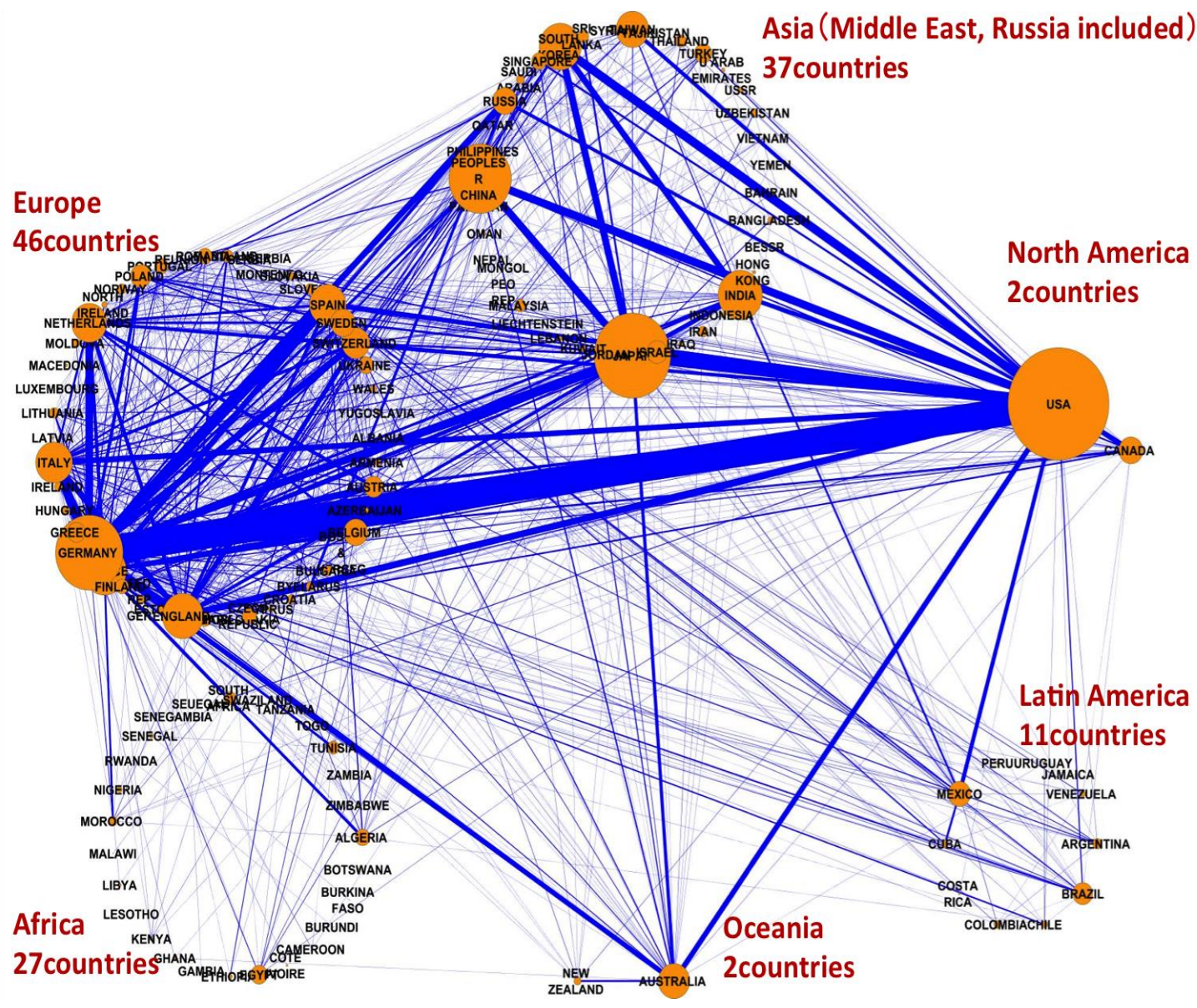

Figure 2(b). Research Network Diagram of Solar Cell

Finally, organizations with a larger number of co-authorships are identified in Table 1 (wind power) and Table 2 (solar cell). In both research fields, pairs of organizations with a larger number of co-authorships are the ones within a same country. Furthermore, there are more co-authorship relations between organizations that have a high competency. The lists of universities and labs involved in tight co-authorship relations are different between both technologies. For instance, Universities and labs in Austria and Russia as well as NASA have a visible presence on wind power. Universities and labs in Scandinavian countries play a key role on both technologies.

Out of the top 30 co-authorship relations of organizations, there are 7 international co-authorship relations (England-Chile, Russia-Austria, Denmark-USA, Austria-USA, Belgium-Netherlands, Austria-Russia, USA-Canada) in wind power research and 5 (Germany-Australia, USA-Germany, Australia-USA, Australia-Netherlands, and Japan-Sri Lanka) in solar cell research. Most pairs are teams of institutions located in the same countries. Therefore, it is considered that geography does matter for research collaboration. Comparing both technologies, there are stronger international co-authorship relations of organizations in wind power research. 
Table 1. Top pairs of institutions in wind power

\begin{tabular}{|c|c|c|c|c|}
\hline Institute1 & Country1 & $\mathbf{N}$ of Papers & Institute2 & Country2 \\
\hline MEIDENSHA CORP & JAPAN & 23 & UNIV RYUKYUS & JAPAN \\
\hline UNIV NOTTINGHAM & ENGLAND & 17 & UNIV MAGALLANES & CHILE \\
\hline RUSSIAN ACAD SCI & RUSSIA & 15 & AUSTRIAN ACAD SCI & AUSTRIA \\
\hline RISO NATL LAB & DENMARK & 14 & INDIANA UNIV & USA \\
\hline UNIV CALIF BERKELEY & USA & 12 & NASA & USA \\
\hline RISO NATL LAB & DENMARK & 12 & TECH UNIV DENMARK & DENMARK \\
\hline NASA & USA & 11 & SW RES INST & USA \\
\hline TECHNOL INST CANARY ISL & SPAIN & 11 & UNIV LAS PALMAS GRAN CANARIA & SPAIN \\
\hline AUSTRIAN ACAD SCI & AUSTRIA & 10 & UNIV NEW HAMPSHIRE & USA \\
\hline UNIV CALIF LOS ANGELES & USA & 10 & NASA & USA \\
\hline UNIV MICHIGAN & USA & 9 & NASA & USA \\
\hline NASA & USA & 9 & JOHNS HOPKINS UNIV & USA \\
\hline NATL TECH UNIV ATHENS & GREECE & 9 & CTR RENEWABLE ENERGY SOURCES & GREECE \\
\hline UNIV COLORADO & USA & 9 & NASA & USA \\
\hline KATHOLIEKE UNIV LEUVEN & BELGIUM & 9 & TECH UNIV EINDHOVEN & NETHERLANDS \\
\hline GRAZ UNIV & AUSTRIA & 8 & AUSTRIAN ACAD SCI & AUSTRIA \\
\hline UNIV COLORADO & USA & 8 & NOAA & USA \\
\hline NASA & USA & 8 & UNIV MARYLAND & USA \\
\hline CALTECH & USA & 8 & NASA & USA \\
\hline UNIV AALBORG & DENMARK & 8 & RISO NATL LAB & DENMARK \\
\hline GRAZ UNIV & AUSTRIA & 7 & RUSSIAN ACAD SCI & RUSSIA \\
\hline UNIV BEIRA INTERIOR & PORTUGAL & 7 & INST SUPER ENGN LISBOA & PORTUGAL \\
\hline FINNISH METEOROL INST & FINLAND & 7 & UNIV HELSINKI & FINLAND \\
\hline MOSCOW MV LOMONOSOV STATE UNIV & RUSSIA & 7 & RUSSIAN ACAD SCI & RUSSIA \\
\hline PAMUKKALE UNIV & TURKEY & 7 & EGE UNIV & TURKEY \\
\hline UNIV HONG KONG & $\begin{array}{c}\text { PEOPLES R } \\
\text { CHINA }\end{array}$ & 7 & SHANGHAI UNIV & $\begin{array}{l}\text { PEOPLES R } \\
\text { CHINA }\end{array}$ \\
\hline UNIV MICHIGAN & USA & 7 & UNIV MARYLAND & USA \\
\hline NASA & USA & 7 & UNIV IOWA & USA \\
\hline NASA & USA & 7 & UNIV ALBERTA & CANADA \\
\hline
\end{tabular}

Table 2. Top pairs of institutions in solar cell

\begin{tabular}{|c|c|c|c|c|}
\hline Institute1 & Country1 & $\mathbf{N}$ of Papers & Institute2 & Country2 \\
\hline CHUBU UNIV & JAPAN & 40 & NAGOYA INST TECHNOL & JAPAN \\
\hline EINDHOVEN UNIV TECHNOL & NETHERLANDS & 37 & DUTCH POLYMER INST & NETHERLANDS \\
\hline LINKOPING UNIV & SWEDEN & 35 & CHALMERS UNIV TECHNOL & SWEDEN \\
\hline NATL TAIWAN UNIV & TAIWAN & 31 & ACAD SINICA & TAIWAN \\
\hline ST PETERSBURG STATE TECH UNIV & RUSSIA & 28 & RUSSIAN ACAD SCI & RUSSIA \\
\hline PEKING UNIV & $\begin{array}{l}\text { PEOPLES R } \\
\text { CHINA }\end{array}$ & 28 & CHINESE ACAD SCI & $\begin{array}{l}\text { PEOPLES R } \\
\text { CHINA }\end{array}$ \\
\hline $\begin{array}{c}\text { FRAUNHOFER INST SOLAR ENERGY } \\
\text { SYST }\end{array}$ & GERMANY & 27 & UNIV NEW S WALES & AUSTRALIA \\
\hline EINDHOVEN UNIV TECHNOL & NETHERLANDS & 26 & UNIV GRONINGEN & NETHERLANDS \\
\hline CNRS & FRANCE & 26 & UNIV STRASBOURG 1 & FRANCE \\
\hline NATL RENEWABLE ENERGY LAB & USA & 25 & $\begin{array}{c}\text { FRAUNHOFER INST SOLAR } \\
\text { ENERGY SYST }\end{array}$ & GERMANY \\
\hline $\begin{array}{l}\text { FRAUNHOFER INST SOLAR ENERGY } \\
\text { SYST }\end{array}$ & GERMANY & 25 & FREIBURG MAT RES CTR & GERMANY \\
\hline UNIV NEW S WALES & AUSTRALIA & 24 & NATL RENEWABLE ENERGY LAB & USA \\
\hline JOHANNES KEPLER UNIV & AUSTRIA & 24 & UNIV GRONINGEN & NETHERLANDS \\
\hline NATL RENEWABLE ENERGY LAB & USA & 24 & COLORADO SCH MINES & USA \\
\hline HASSELT UNIV & BELGIUM & 22 & IMEC & BELGIUM \\
\hline NATL RENEWABLE ENERGY LAB & USA & 22 & UNIV COLORADO & USA \\
\hline UNIV PARIS 06 & FRANCE & 21 & UNIV PARIS 11 & FRANCE \\
\hline UNIV CALIF BERKELEY & USA & 20 & LAWRENCE BERKELEY NATL LAB & USA \\
\hline KATHOLIEKE UNIV LEUVEN & BELGIUM & 20 & IMEC VZW & BELGIUM \\
\hline NASA & USA & 19 & OHIO AEROSP INST & USA \\
\hline DEF LAB & INDIA & 19 & JAI NARAIN VYAS UNIV & INDIA \\
\hline HANYANG UNIV & SOUTH KOREA & 19 & KOREA INST SCI \& TECHNOL & SOUTH KOREA \\
\hline SFA INC & USA & 19 & USN & USA \\
\hline KANAZAWA UNIV & JAPAN & 19 & NIPPON SHOKUBAI CO LTD & JAPAN \\
\hline IND TECHNOL RES INST & TAIWAN & 19 & NATL TAIWAN UNIV & TAIWAN \\
\hline JAPAN SCI \& TECHNOL AGCY & JAPAN & 18 & UNIV TOKYO & JAPAN \\
\hline SHIZUOKA UNIV & JAPAN & 18 & INST FUNDAMENTAL STUDIES & SRI LANKA \\
\hline $\begin{array}{l}\text { UNIV LONDON IMPERIAL COLL SCI } \\
\text { TECHNOL \& MED }\end{array}$ & ENGLAND & 18 & UNIV SHEFFIELD & ENGLAND \\
\hline JILIN UNIV & $\begin{array}{l}\text { PEOPLES R } \\
\text { CHINA }\end{array}$ & 18 & CHINESE ACAD SCI & $\begin{array}{l}\text { PEOPLES R } \\
\text { CHINA }\end{array}$ \\
\hline
\end{tabular}




\section{DISCUSSION}

Although aggregate wind power generation in major countries exceeds that of solar energy [17], the total number of research papers and citations is far greater for the latter. The structure of the research network on wind power is relatively sparse. On the other hand, the rate of international co-authorship is higher for wind power. In addition, the number of participating organizations does not show as large a difference as that of the number of papers. What is the factor behind these phenomena? It is considered that the difference in the maturity of technology plays a major role in creating these differences. Wind power generation was introduced in the 1990s, ahead of solar cells. Wind power has advanced to commercialization quicker than other renewable energy sources, such as solar cells and wave power, with relatively little R\&D expenditure [18]. In fact, public R\&D investment for wind power generation in the US is small. Compared to solar energy, for which innovative technologies such as organic and dye-sensitized solar cell have been developing rapidly since the turn of the century, the technology for wind power matured early. For this reason, international transfer and sharing have also progressed earlier than those for solar energy. It is reasonable to assume that this maturity has influenced the rate of co-authorship and the number of participating organizations.

In addition, characteristics of wind turbines which are core parts of wind power may encourage a role of wide cooperation. The wind turbines have been constructed with more than 10,000 parts. Thus, wider cooperation is needed to comprehend such a complex piece of machinery manufacture.

Next, in terms of research capability, the US, Japan, Germany, China, and India lead others in solar energy, and the US, England, Germany, Denmark, and China lead in wind power. It should be noted that the cost of generating solar and wind power is still higher than that for thermal power. One of the major factors for that is considered to be the strength or weakness of governmental policies, and the stability of governmental commitment. In countries ranking high in the number of papers, strong policies with long-term perspectives have been implemented [19]. Policies include macro target setting, feed-in-tariff, RPS, pricing law, subsidy and Quota requirements. Typical examples of governmental policies include the Advanced Energy Initiative (US), Solar America Initiative (US), Framework Program (FP5 and FP6, EU), Intelligent Energy-Europe (EU), Cool Earth 50 (Japan), Mid-term Development Plan for Renewable Energy (China), the Renewable Energy Law (China) and the Solar Photovoltaic Program (India). Huge public R\&D investment and governmental commitment in the growth potential of markets can also promote academic research. Emergence of an "innovation cycle" has been observed where social demands call for certain policies that enhance knowledgebase and market, ultimately leading to an increased level of social attention and further strengthening of policies.

Asian countries have been improving their research competency at a rate higher than those of the US, Europe, and Japan. This fact shows that catching-up becomes possible by implementing powerful policies. For example, China has been making an extensive effort to develop, verify, and commercialize sustainable energy. Photovoltaic power and wind power among other sustainable energy sources, have become an important source of energy along with atomic, hydroelectric, and biomass power generation [20-22]. The implementation of these large-scale, powerful policies after the turn of the century underlines China's intention to catch-up. The second factor that affects research capability is the natural conditions that are prevalent. In terms of solar energy, power generation efficiency depends largely on insolation. India, which ranks $5^{\text {th }}$ in solar energy (and only $14^{\text {th }}$ in wind power), and sub-Saharan countries in Africa have large insolation, and therefore are more suitable for solar power generation than other countries. For wind power, the efficiency is affected largely by wind speed and the window of time when wind blows. For example, the 
coastlines of England, which ranks second in terms of the number of papers published on the subject, and the northern part and eastern coastal area of China, which ranks $6^{\text {th }}$ in terms of the number of papers published on the subject, have climates suitable for wind power generation [23].

The third factor relates to the historical and institutional differences. Among the Scandinavian countries, Denmark ranks first in research capability. At the same time, Denmark has the highest rate of non-hydro renewable energies for power generation. Although Scandinavian countries have similar backgrounds with respect to stages of national development and natural conditions, there is a large difference in governmental policies regarding wind power [24]. Explicit production support was introduced already in the mid-1980s in Denmark. Denmark has a tradition of local ownership and decentralized production, something which in turn has enabled a high level of local acceptance toward the investment made in wind power [24].

Finally, we would like to discuss various factors behind the co-authorship structure. The first factor is the geographic proximity. There are more co-authorship relations between organizations in the same country or a close spatial proximity in wind power and solar cell research. This corresponds with other previous studies identifying the relationship between co-authorship of organizations and spatial proximity, culture, and language $[3,11,12,14$, 16]. Furthermore, there are more co-authorship relations between organizations with high research competency. The motivation for this may include some of what [25] points out: access to expertise and equipment, to obtain prestige or visibility, to gain tacit knowledge, and to enhance productivity.

The second one is maturity of technology or stage of the development of technology. Although several factors contribute to collaboration in Asia being more advanced in wind power than in solar cell, the maturity of wind power technology makes it fitting for technology transfer. The need for technology transfer leads to research collaboration between countries which have different stages of development.

The third factor is international science and technology policy. Dense co-authorship relations of solar cell research between organizations in Europe are identified. It is highly possible that this is aided by policies in Europe. Solar cell research has been intensively supported by the $5^{\text {th }}$ and $6^{\text {th }}$ EU framework programs (FP5, FP6) that fund research collaborations within EU and between EU and outside countries such as China. The research institutions in China and US had participated in many projects of FP 5 and FP6 [26]. Japan was not so active to participate in the FP 5 and 6. Fig. 3 illustrates the trends of the time series of the number of international co-authorship among continents. Since the start of the FP 5 (1998), number of international collaboration has significantly increased among the EU countries. Cumulative number of research collaboration increased thirty times from 1998 to 2009. A network such as PV European Research Area Network may also contribute to it. The research collaborations between the EU and the US or the EU and Asia also increased significantly after 1998. Especially, collaborations between the US and Germany increased significantly. The collaboration between Japan and Germany is only one-fifth of that. On the other hand, even after the rapid growth of Asian research capabilities, the number of research collaborations among Asian countries remains small. The number is less than one-fifth of the number of cross-border collaborations in the EU region. The number of collaborations between Asia and the US is greater than the number among Asian countries. This is due to the fact that influential international research funding programs do not exist in Asia. It is evident that the difference of the initiative of governments has a significant impact on the progress of cross -border collaboration in these fifteen years. 


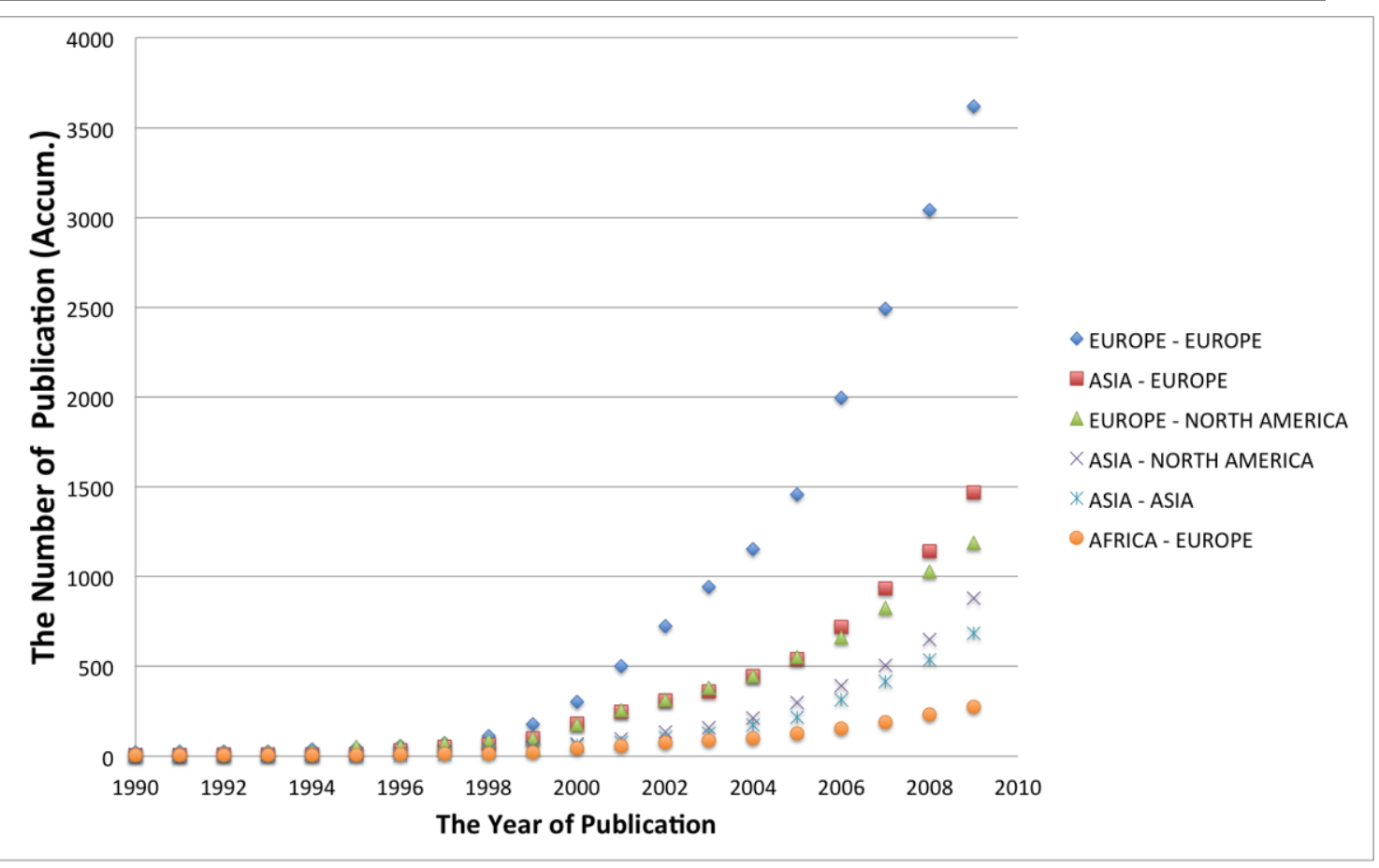

Figure 3. Time Trends of International Collaboration

\section{CONCLUSION}

It has been observed that, for renewable energy, the three factors of market, government policies, and academic research advance simultaneously. This study outlines the development of maps, which consists of the global distribution of research capabilities and collaborative relationships, on the basis of the objective data extracted from 42,600 papers for two renewable energies having high growth potential, such as wind power and solar energy. In the international research network of wind power and solar cell, 4,189 institutions located in 121 countries and 6,600 institutions located in 125 countries are included, respectively.

Then, various factors that influence research capabilities and co-authorship relations are discussed. In terms of research capabilities, the factors related to governmental policies, natural conditions, and historical and institutional differences have been extracted. Factors concerning research collaborations, such as geographical proximity, international science and technology policy, and developmental stage of technology have been brought to attention.

In general, the study demonstrates that bibliometrics is a methodology that is capable of providing a knowledge base that is useful in the development of the international science and technology policy and technological management strategy.

\section{REFERENCES}

1. Lawani, S. M., Some Bibliometric Correlates of Quality in Scientific Research, Scientometrics, Vol. 9, pp.13-25, 1986.

2. Pao, M. L., Co-authorship and Productivity, Proceedings of the American Society for Information Science, Vol. 17, pp.279-289, 1980.

3. Narin, F., Stevens, K. and Whitlow, E. S., Scientific Co-operation in Europe and the Citation of Multinationally Authored Papers, Scientometrics, Vol. 21, No. 3, pp.313-323, 1991. 
4. Sakata, I., Sasaki, H., Nakamura, H. and Kajikawa, Y., Maps of International Research Collaboration in Renewable Energy, Proc. of the $6^{\text {th }}$ Dubrovnik Conference on Sustainable Development of Energy, Water and Environment Systems, Dubrovnik, pp 25-29, Sept. 2011.

5. Levin, R. C., Top of the Class, the Rise of Asia's Universities, Foreign Affairs, Vol. 89, No. 3, pp.63-75, 2010.

6. Shibata, N., Kajikawa, Y. and Sakata, I., Extracting the Commercialization Gap Between Science and Technology - Case Study of Solar Cell, Technological Forecasting and Social Change, Vol. 77, No. 7, pp.1147-1155, 2010. (http://dx.doi.org/10.1016/j.techfore.2010.03.008)

7. Kostoff, R. N., Tshiteya, R., Pfeil, K. M., Humenik, J. A. and Karypis, G., Power Source Roadmaps Using Bibliometrics and Database Tomography, Energy, Vol. 30, pp 709-730, 2005. (http://dx.doi.org/10.1016/j.energy.2004.04.058)

8. Celiktas, M. S., Serigili, T. and Kocar, G., A Snapshot of Renewable Energy Research in Turkey, Renewable Energy, Vol. 30, pp.1479-1485, 2009. (http://dx.doi.org/10.1016/j.renene.2008.10.021)

9. Smith, M., The Trend Toward Multiple Authorship in Psychology, American Psychologist, Vol. 13, pp.596-599, 1958.

10. Frame, J. D. and Carpenter, M. P., International Research Collaboration, Social Studies of Science, Vol. 9, pp.481-497, 1979.

11. Moed, H. F., Bruin, R. E., Nederhof, A. J. and Tijssen, R. J. W., International Scientific Co-operation and Awareness within the European Community: Problems and Perspectives, Scientometrics, Vol. 21, No. 3, pp.291-311, 1991. (http://dx.doi.org/10.1007/BF02093972)

12. Glanzel, W., National Characteristics in International Scientific Co-authorship Relations, Scientometrics, Vol. 51, No. 1, pp 69-115, 2001.

13. Stefaniak, B., International Co-operation in Science and in Social Sciences as Reflected in Multinational Papers Indexed in SCI and SSCI, Scientometrics, Vol. 52, No. 2, pp.193-210, 2001.

14. Hoekman, J., Frenken, K. and Tijssen, R. J. W., Research Collaboration at a Distance: Changing Spatial Patterns of Scientific Collaboration within Europe, Research Policy, Vol. 39, pp 662-673, 2010. (http://dx.doi.org/10.1016/j.respol.2010.01.012)

15. Katz, J. S. and Martin, B. R., What is Research Collaboration?, Research Policy, Vol. 26, pp 1-18, 1997. (http://dx.doi.org/10.1016/S0048-7333(96)00917-1)

16. Schott, T., International Influence in Science: Beyond Center and Periphery, Social $\begin{array}{lllll}\text { Science } \quad \text { Research, } & \text { Vol. }\end{array}$ (http://dx.doi.org/10.1016/0049-089x(88)90014-2)

17. International Energy Agency, Renewables Information 2010, IEA, 2010.

18. Saidur, R., Islam, M. R., Rahim, N. A. and Solangi, K. H., A Review on Global Wind Energy Policy, Renewable and Sustainable Energy Reviews, Vol. 14, pp 1744-1762, 2010. (http://dx.doi.org/10.1016/j.rser.2010.03.007)

19. Iwami, S. and Sakata, I., Classification of Renewable Policies with Indicators of Science and Market, Proceedings of the 21th International Conference for Management of Technology (IAMOT2012), Hsinchu, Taiwan, March 18-22, 2012.

20. Fishlein, M., Larson, J., Hall, D. M., Chaudhry, R., Peterson, T. R., Stephens, J. C. and Wilson, E. J., Policy Stakeholders and Development of Wind Power in the Sub-national Context: A Comparison of Four U.S. States, Energy Policy, Vol. 38, pp 4429-4439, 2010. (http://dx.doi.org/10.1016/j.enpol.2010.03.073)

21. Chai, Q. and Zhang, X., Technologies and Policies for the Transition to a Sustainable Energy System in China, Energy, Vol. 35, pp 3995-4002, 2010. 
22. Wang, F., Yin, H. and Li, S., China's Renewable Energy Policy: Commitments and Challenges, Energy Policy, Vol. 38, pp.1872-1878, 2010. (http://dx.doi.org/10.1016/j.enpol.2009.11.065)

23. Liu, Y. and Kokko, A., Wind Power in China: Policy and Development Challenges, $\begin{array}{llll}\text { Energy Policy, } & \text { Vol. 38, } & \end{array}$ (http://dx.doi.org/10.1016/j.enpol.2010.04.050)

24. Pettersson, M., Soderholm, K. and Soderholm, P., Wind Power Planning and Permitting: Comparative Perspectives from the Nordic Countries, Renewable and Sustainable Energy Reviews, Vol. 14, pp.3116-3123, 2010. (http://dx.doi.org/10.1016/j.rser.2010.07.008)

25. Bozeman, B. and Corley, E., Scientists' Collaboration Strategies: Implications for Scientific and Technical Human Capital, Research Policy, Vol. 33, pp 599-616, 2004. (http://dx.doi.org/10.1016/j.respol.2004.01.008)

26. European Commission, Science, Technology and Competitiveness Key Figures Report, 2008/2009. 